\title{
PSYCHOLOGICAL FEATURES OF GENDER IDENTITY DEVELOPMENT AT YOUNGER SCHOOL AGE
}

\section{Kikinezhdi O. M.}

\section{INTRODUCTION}

The objective of the paper is to follow the development of gender identity at a young school age is caused by the need to study the internal mechanisms of personal identification with certain patterns of sexual behavior, the social need to identify the socio-psychological factors of formation of an egalitarian personality in the context of democratic soiety life and and reformation of national education.

Theoretical analysis of the study made it possible to identify its universal and interdisciplinary character, define the psychological logic of studying gender consciousness differentiation features and identity of the child, depending on the social and educational factors and list the less studied aspects (H. Ball, M. Boryshevskyy, E. Erickson, T. Hovorun, I. Kon, H. Kostyuk, L. Kohlberg, S. Maksymenko, V. Moskalenko). Identity as an integrated personal formation is formed in the process of self-identification with significant patterns of sexual behavior that are widespread in the immediate social environment.

The grade-schooler occupies a special position in the system of public relations because school education activates the process of conscious assimilation of norms of behavior, rights and duties of those normative knowledge and moral feelings that are arisen in pupils under the influence of assessment of a significant adult-teacher. It is known that the younger school age is characterized by the inclusion of the child, on the one hand, in a tougher, than it used to be, system of social and regulatory influences (training), on the other hand - the greater importance of interaction with peers, the mass media, and therefore the strengthening of the horizontal cultural transmission.

The core of the methodology of gender approach in national psychology is the idea of human subjectivity, which is associated with the self-determination of her or his existence in the world, the author's position of the assessment of life events and self-determination in 
various spheres of sexual relations. According to Academician S. Maksimenko, the school demands should take into account the potential of the children, because depends not only on the school achievements, development of personality depend on it, since "the student's success is a measure of subjectivity in their own path: a measure of independence, originality, creativity, flexibility etc"

Scientists stress that the first teacher is the "fully functioning" organizer of the creative and development environment of development of each child's unique "I", regardless of their gender. In the joint activity and dialogue of the teacher and child in elementary school, the "personality of the future" is born as an active and creative subject of activity (M. Boryshevskyi, H. Kostyuk, V. Kravec, S. Maksymenko, R. Pavelkiv, Yu. Prykhodko, M. Savchyn, N. Shevchenko and others).

In our opinion such phenomenon is vividly represented within the humanitarian and phenomenological approaches, and it enables to answer the question about the development of subjectivity, self expression and acquiring of "self" in the contradictions of life. Although the practical aspect of the gender identity question is quite "open", however it has a profound inner layer, as it encompasses a lot of unrevealed psychological mechanisms of personal and spiritual development of a human.

Gender identification plays an important role in the formation of gender self-consciousness of a person, in formation of his/her selfimage, and acquiring the requirements for gender-role behavior. Gender identity characterized as being marked by awareness of gender-role cultural standards as well as social and psychological instructions, accepting the traditional or egalitarian modes of behavior, formation of ego-structures in the continuum of masculinity and femininity, by representation of the individual experience of selfknowledge and attitudes to evaluating oneself and others, by agreement and balancing between the real and ideal gender Self.

In the context of humanistic, genetic and cognitive psychology, and in accordance with the author's model of gender-identity identification of personality, the content characteristics of the gender

${ }^{1}$ Максименко С. Д. Генеза здійснення особистості. Київ : ТОВ “КММ”, 2006. C. 121. 
image of "I" development and the gender perceptions of schoolchildren as subjects of educational activity have been considered.

Identity is an objective process and the result of sexual selfdetermination of the personality, which are represented by the dynamic whole "I am a boy/I am a girl", "I am a man/I am a woman as future adults". The main constructs of gender as a prevailing orientation to the traditional or egalitarian distribution of gender roles in the family and society are reflected in the ambivalent content of the value dispositions of children.

The author's model is based on understanding "gender identity" as a crucial personal formation in the structure of sex self-consciousness, which is manifested in different interactions and attitudes. Masculinity and femininity as individual's attributes are the basic categories in the analysis of sex-role "I" formation. In addition, gender orientations (traditional or egalitarian) are important indicators of individual's selfidentification.

Psychological model demonstrates such principles of gender identity construction: interconnection and interrelation of social and psychological processes of sex-role self-identification on social and individual levels; behaviour differentiation based on individual's sex; asymmetry; polarization-opposition; hierarchy; andro-feminocentrism or egalitarianism, sexism as a biased and stereotyped attitude; evident and "hidden" discrimination, gender stereotypes, etc.

Category of gender was considered by us in the context of psychological concepts of S. Bem, through the prism of theories of gender schemes and lenses, namely polarization, androcentrism and biological essentialism, in this phenomenon there is a certain analogy with the conclusions of L. Vygotsky "symbolic mediation" of psychics, when a cultural sign is a means of organizing the subjective behavior of the individual during his or her maturity. Socialization provides the child's entry into the gender culture of society and is the most important determinant of constructing her gender identity, subjective activity in the process of self-creation of gender "I" according to age, zone of the closest development and leading activity, new formations in mental development. (H. Ball, L. Boshovych, M. Boryshevskyi, I. Bech, T. Hovorun, L. Vygotsky, O. Leontiev, H. Kostyuk, S. Maksymenko, T. Tytarenko and others). 
The problem of gender identification the grade-schooler is poorly researched, so an empirical study of the psychological features of gender identity formation of grade-schooler and the impact of the immediate environment on this process have become the objective of our study.

\section{Program and psychodiagnostic methods of research}

The concept of our study is based on the understanding of gender identity as an important personal formation in the structure of sexual consciousness, which manifests itself in different interactions and attitudes. Masculinity and femininity as personal characteristics serve as basic categories in the analysis of development of genderdetermined "I". Gender orientations (traditional or egalitarian) are an important indicator of personal self-determination. Methodological approaches to the empirical study of the development of gender identity of grade-schooler were based on the developed by us principle of psychological model in the context of the traditional (genderdifferentiated) and personal-development (egalitarian) paradigm ${ }^{2}$.

We have formulated a hypothesis: the development of gender identity of the grade-schooler involves the conscious mastering of new social roles (I-student), which can simultaneously manifest itself in the ambivalence of gender orientations, and the repertoire of gender behavior, which remains flexible for correction. According to the hypothesis, the following tasks were set: 1$)$ to determine the children's perception of the features of the image of I-boy and I-girl, men and women; 2) to find out knowledge and assessment of interests of representatives of their own and opposite gender; 3) to clarify the child's understanding of intra-family and intra-group relations in terms of his or her gender; 4) to find out the psychological and socio-cultural factors that influence on the development of gender identity of the grade-schooler; 5) develop and test an educational program aimed at strengthening the egalitarian behavior of the grade-schooler.

The study considered that the content of gender images of modern man and contemporary woman is an important factor of the development of adequate gender identity of the grade-schooler, which

${ }^{2}$ Кікінежді О. М. Гендерна ідентичність в онтогенезі особистості : монографія. Тернопіль : Навчальна книга - Богдан, 2011. 400 с. 
in the future will facilitate their different orientation of fulfilling future family and social roles. When choosing tasks, we proceeded from the fact that, being free in the choice of images, gender features, children will be guided in their answers, first of all, by their own experience, by internalized gender-role settings.

To identify the semantic field of gender self- and mutual characteristics mastered by grade-schooler, we have modified the following methods: experimental method of semantic differential by S. Bem, semi-projective test of achievements motivation by G. Shmalt, drawing methods "My family", questionnaires (differentiation of verbal aggression, gender identification, methods of identification of the child with parents (A. Zakharov), a content analysis of the content of the image and the desired real "I", the content of standards of gender-behavior by means of the method of unfinished sentences: "women (men) dream about ..." "women (men) should ...", "girls (boys) dream ..." and method of semantic differential, narrative in creating verbal image "ideal" and "real" boy/girl, expert reviews ${ }^{3,4}$.

Factor weight is only considered, there are limits of probability $\mathrm{p}<0,05$ and 0.01 . All statistical operations were performed by using the program Microsoft Excel. The total sample was 111 students, age - 710-years (gender mixed groups were formed on the basis of one class).

\section{Grade-schooler's gender ideas}

Our study confirms the well-known data that grade-schooler (6/7-10 years) is a significant stage in the formation of mental gender, the acquisition of secondary gender identity, since the development of new social roles of children begins at school. The image of the modern woman in the representations of both genders remaines mostly androgynous $(\mathrm{p}<0,001)$ with feminine-masculine and moral qualities. Moreover, girls have a structured and balanced image of the ideal woman ("beautiful, pretty, smart, fashionable, strong, independent, confident, powerful, active ( $\mathrm{p}<0,001)$, while boys supplement it traditional qualities (great housewife).

As children grow older, the cognitive component of the image of the ideal man is getting deeper: independent $(\mathrm{p}<0,001)$ and financially

3 Захаров А.И. Психологические особенности восприятия детьми роли родителей // Вопросы психологии. 1982. № 1. С. 59-67.

${ }^{4}$ Психология детства. Практикум. Тесты, методики для психологов, педагогов, родителей / под ред. А. А. Реана Санкт-Петербург : “Прайм-ЕВРОЗНАК”, 2003. С. 54. 
secure $(\mathrm{p}<0,05)$. Both genders are considered by most children to be less positive, but still male gender is considered stronger and more authoritative than the female $(\mathrm{p}<0,05)$. The image of a typical/real man of schoolchildren with traditional beliefs appears hypermasculine, and women - feminine but positive with androgynous characteristics. The boy's stereotypical representation can be explained by the reproduction of the real gender situation, which in the nearest social environment is characterized by a blanding of gender roles and dominance of androcentrism. It is found out that in the boys' mind the gender portrait of "real" boy and "good" student matches (98\% confluence estimates) with a slight masculine accent (active, courageous, physically strong, smart, dedicated, love adventure and risk, resourceful, capable of winning) the boys' assessment is higher than girls'. The image of a "real" girl and a "good" student in the representations of girls appears mostly androgynous, which includes a fusion of feminine-masculine and moral qualities. Boys attribute more traditional, feminine features to the female image comparing to girls' image of a "good" girl.

According to the nature of gender representations of gradeschooler, there have been identified three groups gender-typed, ambivalent and androgynous. The gender-typed, composed of feminine girls and masculine boys (about 29\%) the sexual preferences of traditional character are emphasized. In this group of children (about $80 \%$ of girls and $90 \%$ - boys) traditional views on games, toys, types of classes and activities dominate. The girls of this group are found more egalitarian about games, toys, interests, desires, activities. "The abivalent group (15\% of children) was characterized by a lack of clarity and ambiguity in the attitudes and behaviors of gender-specific prescriptions inherent in both traditional and egalitarian responses, depending on the context of the life situation. Fragmentation of arguments, uncertainty of what fits and what doesn't fit to specific gender, uncertainty about future family responsibilities and social roles: "I do not know what I will do at home when I will be a grown up", "I do not know what I will be", etc. (40,3\% of boys and only $14 \%$ of girls approve girls' hobbies concerning technical devices).

Girls and boys from the androgynous group (56\% of both sexes) do not separate the world into "male" and "female". $60 \%$ of girls and $50 \%$ of boys are capable of de-stereotyping traditional roles, which is manifested in the unbiased acceptance of unusual, gender atypical activities, doll games for boys, and games with soldiers for girls. The 
motivated acceptance of androgynous gender identity of these children is manifested in the dominant flexibility of gender behavior, a wide range of activities in the situations of personal choice. Their future perspective is full of understanding of open, individual opportunities for developing of boys and girls of the modern professions, such as: businessman, banker, economist, politician, doctor, journalist, director, actor, taxman, judge, musician, scientist, judge etc. The image of the "real" woman in the representations of both sexes is predominantly androgynous $(\mathrm{p}<0,001)$, including the synthesis of feminine-masculine and moral qualities. Their future perspectives are full of understanding of the open opportunities for the development of both boys and girls in modern professions, such as: banker, economist, cosmetologist, pharmacist, designer, engineer, translator, teacher, artist, taxman, judge, musician, businessmen etc. Thus, the children of this group have a tendency to de-stereotype traditional roles. Herewith, girls have a more structured and balanced psychological portrait of a perfect woman at the expense of masculine qualities ("beautiful, stylish, smart, fashionable, well-earned, strong, independent, capable to do everything, courageous, active" ( $p<0,001)$. The boys' female image is complemented by traditional feminine traits and roles (kind, great house wife, caregiver).

The self-identification of grade schoolers with "significant" gender determined parent-adult as a reference circle of the microsocial is a feature of the content of their gender consciousness. The mother remains the model of the "real" woman for $53 \%$ of girls and $49 \%$ of boys, the father - is the "real" man for $40 \%$ and $34 \%$ in accordance. It is reveled that girls, comparing to boys, have got a more detailed picture of the "real" man, whose image is endowed with universal human qualities. Therefore, the gender identification of the grade schooler is acquired under the influence of the new social situation of development - education. The role of the student unifies genderdifferentiated requirements to their behavior, activating the assimilation of both masculine-feminine and moral prescriptions, which deepers the imitation of androgynous patterns of behavior (Fig. 1). 


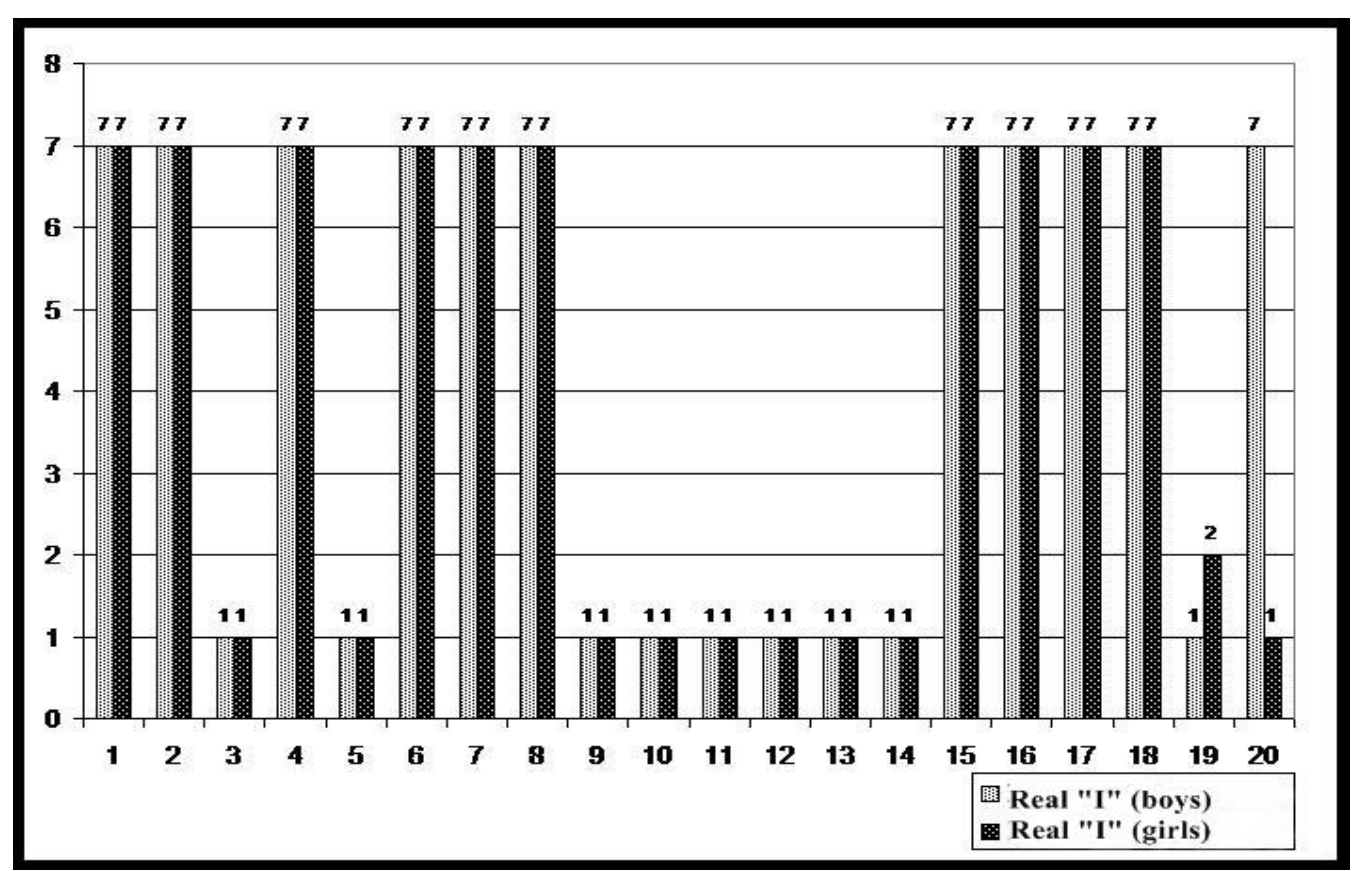

Fig. 1. Gender profiles of the real "I" according to feminine-masculine properties

Note: qualities are: strength (1), weakness (2), rudeness (3), tenderness (4), tearfulness (5), restraint (6), courage (7), cowardice (8), hard work (9), laziness (10), intelligence (11), unintelligence (12), kindness (13), anger (14), accuracy (15), politeness (16), caring (17), beauty (18), compliance (19), perseverance (20).

There have been revealed different orientations of both genders for group interaction and joint participation in preparation for holidays, competitions, etc ( $70 \%$ of girls and $60 \%$ of boys) in the content of the behavioral component of the real "I" of grade schoolers. Most of them are positive about inter-gender relationship as a source of help, which enriches the psychological content of personal interactions at this age. However, there is still a gender differentiation in the orientation towards communication in the gender-homogeneous groups, in the choice of the nature of games, leisure activities and so on.

\section{Content of gender-role identity of grade-schooler}

The content of gender identity is in the identification of grade schoolers with "significant" parent-adult as a reference circle of the micro-society. The mother is the model of the "real" woman for $53 \%$ of girls and $49 \%$ of boys, the father - is the "real" man for $40 \%$ and $34 \%$ respectively. It is revealed, that girls comparing with boys have got a more detailed picture of the male image, endowed with personal, human qualities. Trustful relations with the same-gender 
adults (46\% of girls and $37 \%$ of boys), extention of relations with parents of the opposite sex (43\% of girls and $35 \%$ of boys). The differentiation of gender roles of the grade schoolers can be traced in the content of households $(70 \%$ of girls and $45.2 \%$ of boys clean up, help to cook, pet, $9 \%$ of girls and $16,1 \%$ of boys are able to repair, work in the garden, use house equipment). It has been found out that girls' process of gender identification is taking place in a broader, more specific and coherent role-playing field. Boys' future gender roles are more abstract, with a narrower repertoire of specific skills or norms of behavior.

Thus, the gender self-esteem of a child with an emphasis on moral qualities as a result of the direct transfer of holistic perceptions by adults of her biological sex, forms the basic gender-role idea: "I am a good boy/a good girl" or "I am a bad boy/a bad girl". Such a transposed and assigned holistic attitude to oneself as a representative of a certain gender "I am, as a boy/girl, know, want, know" is mediated by gender knowledge, which, internalizing through the prism of emotional experiences, intellectual-volitional comprehension of the child, becomes a cause of self-analysis, self-reflection, attainment of the conscious desired image of the (ideal) "I", aiming for androgynous or stereotyped behavior in the future (Fig. 2).

Therefore, the gender identification of the grade schooler is acquired under the influence of the new social situation of development - education. The role of the student unifies genderdifferentiated requirements for their behavior, activating the assimilation of masculine-feminine and moral prescriptions, which develops an androgynous model of gender behavior. Found similarities in the structure of the desired I (good school girl/boy) in both genders (saturation of significant positive traits of intellectual and volitional and masculine qualities), such as: courage, strength, determination, intelligence which can be a prerequisite for the development of selfreflection and self-categorization, which is consistent with the conclusions of scientists: I. Bulakh, L. Dolynskaya, V. Kotyrlo, R. Pavelkiv, Yu. Prykhodko, N. Shevchenko. The revealed similarity of the semantic structure in the images of the ideal and the real self of both samples indicates a tendency towards androgynous gender identity, which finds its manifestation in the behavior, values, sexual beliefs of the desired (moral) qualities of the student. 


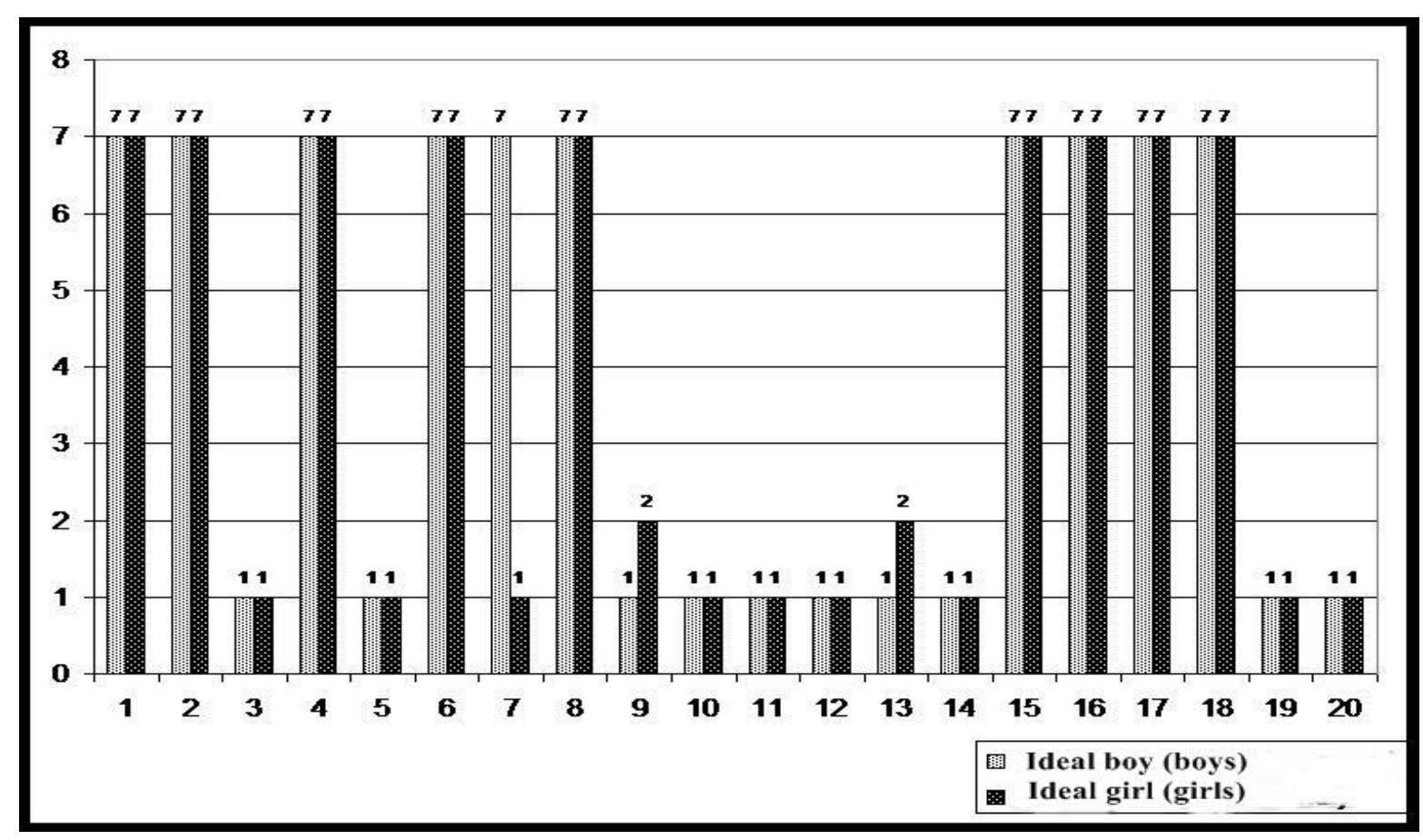

Fig. 2. Gender profiles of the ideal "I" for feminine-masculine qualities

Note: qualities are: strength (1), weakness (2), rudeness (3), tenderness (4), tearfulness (5), restraint (6), courage (7), cowardice (8), hard work (9), laziness (10), intelligence (11), unintelligence (12), kindness (13), anger (14), accuracy (15), courtesy (16), caring (17), affection (18), perseverance (19), perseverance (20).

Similarity in the structure of the desired "I" is proved by the findings of research of I. Bulakh, R. Pavelkiv, Yu. Prykhodko, N. Shevchenko, which focus on the latent period of development of sexual consciousness, which are characterized by orientation to moral principles of behavior regardless of gender. Along with the similarity of the semantic structure of images of the real self of boys and girls, the varified differences relate to boys' greater focus on masculine achievements - higher, harder, stronger. In the image of the real and desired "I" of girls, these "masculine" achievements are balanced by the high appreciation of feminine heritage. The peculiarity of ideal gender images for boys imitation deepends on internal "conflict" (the ideal boy is courageous, fearless, combative, and the ideal student is responsible, polite, obedient). As for the girls, the ideals of "a good" student and a "real" girl do not contradict each other, which gives impetus to the "weak" sex to choose a wider range of models of gender behavior for imitation cinema, literature, real and imaginary characters from the life of the closest people. A boy-grade-schooler begins to 
reorient from being an adult as a "significant other" into the identification with the behavior of peers, that deepers the mechanism of self-reflection.

The age dynamics of the cognitive component of the image of the ideal man is manifested in his masculinization (independent $(\mathrm{p}<0,001)$, financially secure $(p<0,05)$, since the representatives of both sexes consider the male gender stronger and more authoritative than the female $(p<0,05)$. If the image of a typical/real man in both sexes appears masculine, then the "real" woman is androgynous and feminine The greater stereotypical representation of boys than girls can be explained by the mechanism of reproduction - the simulation of the real gender situation, which in the closest social environment is characterized by the contradiction of gender roles and the dominance of androcentrism. The lack of statistically significant differences in the motivation of achievement of representatives of different genders is another confirmation of the internalization of the role of the student in the image of the ideal "I", which becomes integrated in the fulfillment of the new social roles and may manifest itself in the internalization of androgynous models of gender-role behavior.

\section{Features of gender differentiation of grade schoolers}

The specificity of gender differentiation of grade schoolers is clearly manifested in the characteristics and content of achievement motivation. According to the results of the G. Schmalt test, it was found that girls grade schoolers comparing to boys grade schoolers have higher grades on all achievement motivation scales (except the "fear of failure") (Table 1). 
Diagnostic indicators of grating motivation achievement in boys and girls of primary school age

\begin{tabular}{|c|c|c|}
\hline Scales & Crazy chicks & Girls to a \\
\hline $\mathrm{A}(1)$ & 25 & 27 \\
\hline B (2) & 24 & 26 \\
\hline In (3) & 25 & 26 \\
\hline $\mathrm{D}(4)$ & 23 & 25 \\
\hline E (5) & 24 & 24 \\
\hline E (6) & 26 & 27 \\
\hline $\mathrm{A}+\mathrm{E}(7)$ & 51 & 53 \\
\hline $\mathrm{C}+\mathrm{D}(8)$ & 48 & 50 \\
\hline $\mathrm{B}+\mathrm{D}(9)$ & 48 & 50 \\
\hline Indus (10) & 71 & 80 \\
\hline Soc 11) & 48 & 50 \\
\hline OU (12) & $5 *$ & $7 *$ \\
\hline BN 1 (13) & 6 & 4 \\
\hline BN 2 (14) & 3 & 4 \\
\hline MR 1 ( 15) & 11 & 12 \\
\hline MR 2 (16) & 8 & 11 \\
\hline HN 1 (17) & 0 & 3 \\
\hline CH $2(18)$ & 3 & 3 \\
\hline
\end{tabular}

Note: * significance of differences by Student's test at $p=0,05 ; A$-labor, craft; $B$-artistic activity; $B$-educational activity; $D$-sphere of self-affirmation; E-assistance activities; E-sport. A+E-sphere of traditionally male world; $B+$ $D$-sphere of the traditionally fempde world; $C+G$-sphere of gender-neutral activities; Indus - individual values; social norms; HY hope for success; BNI active avoidance of failure; BN2 - fear of failure; ZM1-general motivation 1; ZM2-general motivation 2; CH1- "Pure Hope 1"; ChN2 is "pure hope 2". Scales 1-11-avarage mean; scales 12-18-stanine.

However, the results of "hope for success" are higher for boys comparing to girls $(7,2: 5,4)$. The lack of statistically significant differences in the achievement motivation of representatives of different genders is another confirmation of the internalization of the role of the grade schooler boy/girl in the image of the ideal "I". Orientation on the respect of masculinity in the achievement motivation of boys is confirmed by the data their conscious assimilation of various forms of aggressive behavior (both verbal and physical).

Gender differences of grade schoolers' perceptions of "male" and "female" respond to socio-psychological expectations of school life 
norms and rules, and fulfillment of educational tasks as subjects of educational activity. The specifics of the content of the gradeschoolers' gender perceptions of the ideal "I" consist of filling them with androgynous standards of behavior. The cognitive component of gender identity is enriched by accepting the challenges of the new social situation - to study successfully, to integrate masculine-feminine and moral qualities. The revealed identity of the semantic profiles of the images of gender I am ideal/I am real in the representatives of both sexes points to the unification of the acceptance of the role of the grade schooler girl/boy, which is caused by the growing reflection as a new reality, actualized by school education, which requires androgynous qualities. In this case, there are two different trends: the deepening of gender segregation (communication with representatives of similar gender) and the convergence of genders (communication with representatives of another gender) (E. Makobi), which is the basis of the discovery and development of two children's subcultures: "girl" and "boy", which later begin to be differentiated by dichotomy and opposition in behavior.

During the adulthood, by the end of younger school age, the girls' and boys' content of gender images (the relation between the self-real and the self-ideal) is enriched with new value - significant-coordinates of the direction of their differentiation. At the same time, positive correlations between the androgynous type of gender identity and the pursuit of success, the setting of difficult tasks, and the self-concept of ability adequacy were revealed.

The main psychological mechanism for the development of gender identity of the grade schooler is still the role model, but the reflection is deepening, which contributes to the assimilation of different types of sexual behavior. The girls' process of gender identification unfolds in a broader and more specific and more consistent gender-role range, boys' ideal gender roles and qualities are more abstract, with a narrower repertoire of specific skills or norms of behavior.

\section{Gender landmarks of the family}

Parents have been found to play a leading role in the development of gender identity of children, but only $36 \%$ of the surveyed adults have an understanding of the foundations of gender ideology and gender education (for example, the consequences of traditional upbringing as a phenomenon of "acquired helplessness" of sons and daughters). The majority of respondents (54\%) gave a positive answer to the statement: 
"The fact that boys play little dolls is the reason that they grow up and become "silent" dad and that "little girls are not interested in technology, leads to women-adults who are helplessness with various appliances"(63\% of dads and moms supported this view). However, there is one common feature in the demonstrated unity of acceptance of traditional gender guidelines - the average score of self-esteem, which in total attests to the ambivalence of gender guidelines, uncertainty about the truthfulness of the chosen educational position. In addition, this conclusion follows from the distribution of parents' affirmative answers to questions which content is rather egalitarian.

The level of parental requirements for girls' adherence of traditional behaviors (household and caring skills) is significantly higher for girls than for boys (3:1). An analysis of the focus group protocols, which consisted of the parents of the grade schoolers (73 samples) shows the liberalization of their views. In this case, fathers were more democratic than mothers. For example, mothers of boys, and more often their fathers, warn them against "sexually inappropriate" (in their opinion) skills, such as mastering the secrets of cooking, culinary delicacies and more. At the same time, girls, on the contrary, are more involved in the understanding of the work of house equipment, as well as household duties, which are usually done by the opposite gender. Personal comparison with the opposite gender and the contrasting to it used by parents to their sons to turn them to the path of "gender acceptance": "You're not a girl to ...". The correspondence of such gender correspondences of positive answers in the upbringing of boys is $3: 1$, respectively. Despite the declaration of traditional gender preferences, the majority of parents of grade schoolers (96\%) support the idea of mixed gender schools rather then single gender schools.

Thus, the emergence of the construct of the ideal "I" and its integration into the real "I" of grad schoolers is made mainly in the process of internalization of the androgynous construct of masculinityfemininity as personality-oriented requirements for the development of the child. Therefore, the overall conclusion of the monitoring of parents' gender preferences can be following: adults (mainly parents of grade schoolers), middle-aged people, feel rather frustrated about the questions of gender self-determination and gender education of children-gradeschoolers, then support traditional or egalitarian positions.A small amount of parents have got a strict position. The overwhelming majority of them agreed with the points of view, which contradict each other: on 
the one hand - rejection of the idea of gender inequality of children and adults, on the other - lack of understaing what pedagogical requirements from parents will allow their children to grow up as "real" men and women. However, the vast majority is afraid of possible gender-biased deviations in the case of ignoring the traditional role distribution. Parents of grade-schoolers need gender knowledge, particularly those which debunk gender stereotypes about the natural purpose of male and female roles in the family and society. Behind the prevalence of ambivalent gender educational positions, there is an immature need to go beyond gender bias and the lack of scientific information about the alternative, namely egalitarian, ways of gender socialization, based on a personal approach to the education at school and at home. Gender stereotyping of parents is quite clearly manifested in the assimilation of gender stereotypes of grade-schoolers regarding the evaluation of the behavior of the opposite gender that children thoughtlessly accept as the "opposite". At the same time, these "heard" judgments are quite easily debunked in the process of additional, auxiliary questions, which testify the need to include gender education in the elementary education process. The main task of adults is not to limit children by stereotypical conclusions about the "male" and "female" professions and create all conditions for the development of skills in the process of studying different school subjects and extracurricular activities.

Thus, the specificity of gender identity of the grade schooler depends on the gender preferences of the parents. It has been found that the level of parental requirements for girls' of traditional principles of behavior is much higher than for boys. Differentiated presentation of genders in polar socio-psychological spheres leads to difficulties for children in gender self-determination as a future scenario of a growing personality.

\section{CONCLUSIONS}

The empirical generalization of the results of the study allowed us to determine the characteristics of gender identity of the grade schooler, the correspondence of gender perceptions about "male" and "female" to socio-psychological expectations about the rules and norms of school life, the implementation of the rules of students' behavior as subjects of the school life .

The following psychological patterns have been identified: 1) the development of two divergent tendencies is observed: deepening of 
gender segregation (communication with representatives of the same gender) and convergence of genders (communication with representatives of the opposite gender), which is the basis of the origin and development of two teenage subcultures: "girls" and "boys", which later will be distinguished by dichotomy and opposition; 2) the cognitive component of gender identity is enriched by taking the challenges of the new social situation; 3) in order to study successfuly, the masculinefeminine and moral qualities in the behavior should be integrated, which further develops androgynous personality traits; 4) Positive correlations between the androgynous type of gender identity and higher aspirations for success are revealed, the setting of difficult tasks of younger students indicates the mechanism of assignment of the "implicit gender models" of grade schooler in the social environment of the "implicit gender models" of young people.

Since the grade schooler is the most sensitive to the formation of egalitarian gender perceptions, it should be as much as possible filled with practice of gender parity. The high level of reconciliation between the correlation of the real and desired image of the "I-Gender" of the grade schooler indicates the development of mechanisms of reflection and decentration, which indicates the transition to another stage of the development of gender identity as a personal formation from nondifferentiated and non-personalized ideas of gender "ideal" to its generalization as a result of the activation of the reflection mechanism. Thus, the process of gender identification of the grade schooler is characterized by the transition from abstract ideals of men and women to their gradual interiorization by individualizing of models as representations of the ideal and real "I".

A high level of concordance between the ratio of actual and the desired image of "I-gender" is, in our view, a precondition for the development of mechanisms for reflection and decentration, indicating that phasic (gradual) nature of the formation of gender identity as personal education at this age: from undifferentiated and specific gender ideas about "ideal" for the older preschoolers to their differentiation and synthesis, which is reflected in combination of femininemasculine characteristics with moral, their integration into an rohinnomu image "I" have younger students, expanding the repertoire of gender behavior in both sexes. Thus, the process of gender identification in the early school years is characterized by the gradual emergence androgynous image I from deepening primary gender 
identity of his "I" (physical traits, physical I), the reflexive ideas about the ideal and the real I (own individual abilities and opportunities feminine - muscular traits, volitional and intellectual), their deepening and generalization, expanding the repertoire of behavior due to active, personal perception of the desired ideal self as subjects of educational activity.

The formation of gender identity in a younger schoolboy is due to the assignment of "implicit gender models" that have been tried and approved by the closest social environment. This age is the most sensitive in the context of the formation of egalitarian gender perceptions in connection with the development of the new social role of the grade schooler, which is characterized by the flexibility of sexual behavior, and its approach to androgynous.

\section{SUMMARY}

The article deals with the results of an empirical study of gender identity development at younger school age. In the context of humanistic, genetic and cognitive psychology, and in accordance with the author's model of gender-identity identification of personality, the content characteristics of the gender image of "I" development and the gender perceptions of schoolchildren as subjects of educational activity have been considered.

Identity is an objective process and the result of sexual selfdetermination of the personality, which are represented by the dynamic whole "I am a boy/I am a girl", "I am a man/I am a woman as future adults". The main constructs of gender as a prevailing orientation to the traditional or egalitarian distribution of gender roles in the family and society are reflected in the ambivalent content of the value dispositions of children.

The following psychological patterns have been identified: deepening gender segregation and convergence of sexes; enrichment of the cognitive component of gender identity; integration of masculinefeminine and moral qualities in the behavior as a basis for the development of androgyny of personality. A high level of harmonization between the correlation of the real and desired image of the "I-Gender" of the young students has been noted. It indicates the development of mechanisms of reflection and decentration.

Three groups of gender identity varieties have been identified: sexually typed, ambivalent, and androgynous. Uniformity in the content 
of the gender images of real "I" and ideal "I" in the representatives of both sexes involves the integration of feminine-masculine and genderneutral (moral) qualities, which demonstrates the formation of a new social position - the status of schoolboy/schoolgirl. By the end of primary school age, the content of gender images of girls and boys (the ratio of real "I" and ideal "I") is enriched with new value-meaning coordinates in the direction of their differentiation. Positive correlations between the androgynous type of gender identity and success, setting difficult targets, and I-concept of the adequate availability of ability are established.

\section{REFERENCES}

1. Балл Г. О., Мєдінцев В. О., Нікуленко О. О. та ін. Гуманістичні орієнтири в методології психологічної науки: монографія / за ред. Г. О. Балла. Київ : Педагогічна думка, 2007. $98 \mathrm{c}$.

2. Божович Л. И. Личность и ее формирование в детском возрасте. Москва : Просвещение, 1968. 464 с.

3. Боришевський М. Й. Дорога до себе: від основ суб'єктності до вершин духовності : монографія. Київ : Академвидав, 2010. 416 c.

4. Выготский Л. С. Собрание сочинений : в 6 томах / под ред. А. Р. Лурия, М. Г. Ярошевского. Москва : Педагогика, 1982. Т. 1. 488 c. ; T. 2.504 c.

5. Дуткевич Т.В. Дитяча психологія : навчальний посібник. Київ : Центр учбової літератури, 2012. 424 с.

6. Захаров А.И. Психологические особенности восприятия детьми роли родителей. Вопросы психологии. 1982. № 1. С. 59-67.

7. Кікінежді О. М. Гендерна ідентичність в онтогенезі особистості : монографія. Тернопіль : Навчальна книга - Богдан, 2011. $400 \mathrm{c}$.

8. Костюк Г. С. Навчально-виховний процес i психічний розвиток особистості. Київ : Радянська школа, 1989. 608 с.

9. Кравець В. П., Говорун Т. В., Кікінежді О. М. Гендерна соціалізація молодших школярів : навчальний посібник. Тернопіль : Навчальна книга - Богдан, 2011. 192 с.

10. Максименко С. Д. Генеза здійснення особистості. Київ : TOB "КМM", 2006. 240 с.

11. Павелків Р. В. Системно-феноменологічний аналіз генезису моральної свідомості та самосвідомості у молодшому шкільному 
віці. Актуальні проблеми соціології, психології, педагогіки: зб. наук. пр. Київ : Логос, 2011. Т.4. С. 108-118.

12. Приходько Ю. О. Нариси становлення та розвитку дитячої психології: навч. посіб. [для вищих навч. закладів]. Київ : НПУ ім. М. П. Драгоманова, 1999. 205 с.

13. Психология детства. Практикум. Тесты, методики для психологов, педагогов, родителей / под ред. А. А. Реана. СанктПетербург : "Прайм-ЕВРОЗНАК”, 2003. 224 с.

14. Савчин М. В. Вікова психологія. Київ : Академвидав, 2011. $368 \mathrm{c}$.

15. Скрипченко О. В., Долинська Л. В., Огороднійчук 3. В. та ін. Вікова та педагогічна психологія : навчальний посібник ; 2-ге вид. Київ : Каравела, 2007. 400 с.

16. Шевченко Н. О. Особистість молодшого школяра. Київ : Главник, 2008. 128 с.

17. Bem S. Sex-role adaptability: One consequence of psychological androgyny. Journal of Personality and Social Psychology. 1975. No. 31. P. 634-643.

18. Hyde J.-Sh. Half the Human Experience: The Psychology of Women. Lexington - Massachusetts - Toronto, 1991. 475 p.

19. Kohlberg L. A., Ulian D. Z. Stages in the development of psychosexual concepts and attitudes / R. S. Friedman, R. M. Richart \& R. L. Varge Wiete (Eds.), Sex Differences in behavior. New York: Wiley, 1974.

20. Maccoby E. E., Jacklin C. N. The Psychology of Sex Differences. Stanford. CA : Stanford University Press, 1974. 391 p.

\section{Information about the author: Kikinezhdi O. M.}

Doctor of Psychological Science, Professor, Head of the Psychology Department, Director of the Scientific Research Centre of the Problems of Gender Education and Upbringing Pupils and Students of NAPS of Ukraine, Ternopil Volodymyr Hnatiuk National Pedagogical University 2, Maxyma Kryvonosa str., Ternopil, 46027, Ukraine 